Cite this: J. Mater. Chem. A, 2013, 1 9889

Received 10th May 2013

Accepted 20th June 2013

DOI: $10.1039 / c 3 t a 11849 e$

www.rsc.org/MaterialsA

\section{Phosphorus-doped porous carbons as efficient electrocatalysts for oxygen reduction}

\author{
Jiao Wu, ${ }^{a}$ Zhenrong Yang, ${ }^{a}$ Xiaowei Li, ${ }^{b}$ Qijun Sun, ${ }^{c}$ Chao Jin, ${ }^{a}$ Peter Strasser ${ }^{d}$ \\ and Ruizhi Yang*a
}

\begin{abstract}
Efficient electrocatalysts for the oxygen reduction reaction (ORR) play a critical role in the performance of fuel cells and metal-air batteries. In this study, we report a facile synthesis of phosphorus (P)-doped porous carbon as a highly active electrocatalyst for the ORR. Phosphorus-doped porous carbon was prepared by simultaneous doping and activation of carbon with phosphoric acid $\left(\mathrm{H}_{3} \mathrm{PO}_{4}\right)$ in the presence of Co. Both phosphorus and cobalt were found to play significant roles in improving the catalytic activity of carbon for the ORR. The as-prepared phosphorus-doped porous carbon exhibited considerable catalytic activity for the ORR as evidenced by rotating ring-disk electrode studies. At the same mass loading, the Tafel slope of phosphorus-doped porous carbon electrocatalysts is comparable to that of the commercial Pt/C catalysts (20 wt\% Pt on Vulcan XC-72, Johnson Matthey) with stability superior to Pt/C in alkaline solutions.
\end{abstract}

\section{Introduction}

Fuel cells and metal-air batteries are promising technologies for portable, residential and especially transportation applications due to their high energy densities, low operating temperature and environmental compatibility. ${ }^{\mathbf{1 - 4}}$ It is well known that the slow kinetics of the oxygen reduction reaction (ORR) at the cathode limits the efficiency of fuel cells and metal-air batteries. ${ }^{5-9}$ The exploration of efficient electrocatalysts for the ORR is highly desirable for these energy storage and conversion devices. Platinum-based electrocatalysts are widely used for the ORR. However, Pt is expensive and scarce, which hinders the widespread commercialization of fuel cells and metal-air batteries.

Research efforts have been focused on replacing Pt with less expensive materials. Carbon-based catalysts doped/functionalized with heteroatoms have been explored as alternative electrocatalysts for the ORR due to their relatively high abundance and low cost. ${ }^{10-13}$ By doping with heteroatoms, the physical and chemical properties of carbon can be modified and new sites can even be created, which make the catalytic activities of carbon tailorable. Nitrogen (N)-doped carbons, such as $\mathrm{N}$-doped porous carbon, ${ }^{\mathbf{1 0}, 13} \mathrm{~N}$-doped carbon nanotubes ${ }^{\mathbf{1 1}}$ and $\mathrm{N}$-doped

\footnotetext{
${ }^{a}$ School of Physical Science and Technology, School of Energy, Soochow University, Suzhou, Jiangsu 215006, China.E-mail: yangrz@suda.edu.cn; Tel: +8651265221519 ${ }^{b}$ Institute of Chemical Power Sources, Soochow University, Suzhou, Jiangsu 215006, China

${ }^{c}$ College of Nanoscience \& Technology, Soochow University, Suzhou, Jiangsu 215006, China

${ }^{d}$ The Electrochemical Energy, Catalysis, and Materials Science Laboratory, Department of Chemistry, Chemical Engineering Division, Technical University Berlin, 10623 Berlin, Germany
}

graphene, ${ }^{12}$ are the most studied carbon-based catalysts for the ORR. Nitrogen, an electron donor, can provide n-doping and therefore increases the conductivity of carbon. ${ }^{\mathbf{1 4}}$ Furthermore, doping of carbon with $\mathrm{N}$ induces electronic structure changes (like charge redistribution and charged sites $\left(\mathrm{C}^{+}\right)$creation $)^{\mathbf{1 1 , 1 5}}$ as well as structural changes (like high plane edge exposure), ${ }^{\mathbf{1 6 , 1 7}}$ which are reported to contribute to the enhancement of kinetics of the ORR. ${ }^{11,15-18}$ To further increase the catalytic activity of carbon, other dopants were explored. The doping of carbon with boron (an electron acceptor) was also reported to show high catalytic activity for the ORR due to the fact that the charged sites $\left(\mathrm{B}^{+}\right)$created by the B-doping are favorable for $\mathrm{O}_{2}$ adsorption and facilitate the ORR. ${ }^{12,19-21}$ Phosphorus (P) is another doping heteroatom being of thriving interest since $\mathrm{P}$ is also an electron donor and can be incorporated into carbon. Density functional theory (DFT) studies on P-doped single walled carbon nanotubes (SWCNTs) have shown that P-doping modifies the electron transport properties and presents affinity towards acceptor molecules (as $\mathrm{O}_{2}$ ), which make P-doped carbons more efficient electrocatalysts. ${ }^{22,23}$ Recently, Liu et al. reported that P-doped graphite layers and multiwalled carbon nanotubes exhibited promising ORR activity in basic media. ${ }^{24,25}$ Studies on $\mathrm{P}$ and $\mathrm{N}$ co-doped nanocarbons ${ }^{26-28}$ have shown that additional P-doping improves the catalytic activity of $\mathrm{N}$-doped carbon for the ORR. Although N-doped carbons as electrocatalysts for the ORR have been widely investigated, synthetic methods towards P-doped carbons and the electrocatalytic activities of P-doped carbons for the ORR are still seldom reported.

In this work, we report the synthesis of P-doped porous carbon in the presence of Co. Sugar and phosphoric acid were used as sources of carbon and $\mathrm{P}$, respectively. $\mathrm{Co}\left(\mathrm{NO}_{3}\right)_{2}$ was 
used as the Co source. The electrocatalytic activities of the assynthesized P-doped porous carbon for the ORR in alkaline media were investigated. The as-synthesized P-doped porous carbon exhibited a high ORR electrocatalytic activity and longterm stability, outperforming pure carbon, carbon functionalized with Co, and P-doped carbon synthesized in the absence of $\mathrm{Co}$, and is comparable to the commercially available $\mathrm{Pt} / \mathrm{C}$ catalyst (20 wt\% Pt on Vulcan XC-72R, Johnson Matthey). Both the effects of $\mathrm{P}$ and Co on the electrocatalytic activity of carbon are discussed. Co was found to be an important factor in improving the catalytic activity of P-doped porous carbon for the ORR.

\section{Experimental}

\subsection{Sample preparation}

Carbon was prepared by a hydrothermal method with sugar as the precursor as reported in our previous study. ${ }^{29}$ Briefly, the sugar was dehydrated at $190{ }^{\circ} \mathrm{C}$ in a stainless steel autoclave and then pyrolyzed at $1000{ }^{\circ} \mathrm{C}$ in a tube furnace in a nitrogen atmosphere. $\mathrm{Co}\left(\mathrm{NO}_{3}\right)_{2}$ was added to the carbon samples by the imbibing method..$^{30}$ For $500 \mathrm{mg}$ samples of carbon, $650 \mu \mathrm{L}$ of 2.0 $\mathrm{M} \mathrm{Co}\left(\mathrm{NO}_{3}\right)_{2} \cdot 6 \mathrm{H}_{2} \mathrm{O}(\geq 99.0 \%$, Guoyao Chemical Reagent Co. Ltd.) was added to carbon. Then the samples were dried at $100{ }^{\circ} \mathrm{C}$ overnight. The samples obtained were abbreviated to $\mathrm{Co}-\mathrm{C}$. Phosphoric acid was added to $\mathrm{Co}-\mathrm{C}$ with a weight ratio of phosphoric acid : $\mathrm{Co}-\mathrm{C}=5: 1$. The mixture was kept at $85{ }^{\circ} \mathrm{C}$ for $3 \mathrm{~h}$. The solvent in the mixture was removed in an evaporator operated at $85{ }^{\circ} \mathrm{C}$ and $300 \mathrm{mbar}$. The paste mixture obtained was then dried overnight in an oven at $85^{\circ} \mathrm{C}$. After grinding, the powder was loaded into a graphite boat and then pyrolyzed under a $\mathrm{N}_{2}$ atmosphere with a rate of $3{ }^{\circ} \mathrm{C} \min ^{-1}$ and kept at $800{ }^{\circ} \mathrm{C}$ for 1 hour. The pyrolyzed samples were stirred in $500 \mathrm{~mL}$ of $1.0 \mathrm{M} \mathrm{HCl}$ solution for $12 \mathrm{~h}$ to dissolve the residual Co in the carbon. Finally, the samples were washed with ultrapure water until neutral $\mathrm{pH}$ was reached and then dried in an oven at $90{ }^{\circ} \mathrm{C}$. The samples obtained were abbreviated to $\mathrm{P}(\mathrm{Co})-\mathrm{C}$. The samples were also prepared with the same procedure in the absence of Co for comparison, which were abbreviated to $\mathrm{P}-\mathrm{C}$.

\subsection{Physical characterization}

The crystal structure of the sample was examined with X-ray diffraction (XRD) using a Bede D1 X-ray diffractometer (UK, Bede Scientific Ltd.; $\mathrm{Cu} \mathrm{K} \mathrm{K}_{\alpha}$ radiation; operated at $40 \mathrm{kV}, 45 \mathrm{~mA}$; $\lambda=0.15418 \mathrm{~nm}$ ), the diffraction angle ranging from $10^{\circ}$ to $80^{\circ}$ with a step of $0.02^{\circ}$ and a rate of $1.2^{\circ} \mathrm{min}^{-1}$.

Raman spectroscopy of the sample was performed on a Jobin Yvon LabRAM HR 800 instrument with a $514 \mathrm{~nm}$ excitation laser at a power of around $1 \mathrm{~mW}$.

Surface analysis of the samples was performed with a SSI (Surface Science Instruments) X-ray photoelectron spectroscopy (XPS) spectrometer equipped with a hemispherical analyzer and using a monochromatized $\mathrm{Al} \mathrm{K} \alpha(1486 \mathrm{eV})$ source with a $250 \times$ $1000 \mu \mathrm{m}$ illumination spot. The measurement parameters were as follows: $20 \mathrm{eV}$ pass energy, $0.1 \mathrm{eV}$ energy increments. The spectra were corrected for the background using the Shirley approach $^{31}$ and the composition of the films was determined by measuring the ratio of $\mathrm{C} 1 \mathrm{~s}$ to $\mathrm{P} 2 \mathrm{p}$ intensities (integrated peak area) normalized by their respective sensitivity factors. ${ }^{32}$

The specific surface area and the pore structure of the samples were analyzed by adsorption/desorption measurements of nitrogen at $77 \mathrm{~K}$ (Quantachrome, QuadraSorb SI). Prior to measurements, the samples were degassed at $250{ }^{\circ} \mathrm{C}$ overnight under vacuum. Surface area was calculated by the Brunauer-Emmett-Teller (BET) method, micropore volume from $\mathrm{N}_{2}$ sorption was calculated using the $t$-plot method. Pore size distributions were calculated using the Horvath-Kawazoe (HK) method.

The morphology of the sample was examined with scanning electron microscopy (SEM, FEI Quanta 200) equipped with EDS.

The amounts of $\mathrm{P}$ and residual metals in the carbons were measured with inductively coupled plasma-atomic emission spectroscopy (ICP-AES) analysis (Vista MPX).

\subsection{Electrochemical measurements}

Inks of the catalyst samples were prepared by mixing $10 \mathrm{mg}$ of powder, $5 \mu \mathrm{L}$ of Nafion solution ( $5 \%$ wt from Aldrich), and $350 \mu \mathrm{L}$ of ethanol, followed by ultrasonicating for 40 minutes. $7 \mu \mathrm{L}$ of ink was pipetted onto a glassy carbon (GC) disk resulting in a powder loading of $1006 \mu \mathrm{g} \mathrm{cm} \mathrm{cm}^{-2}$.

The electrocatalytic activity for the ORR of the samples on the GC disks was studied with the rotating ring-disk electrode (RRDE) technique using a Pine electrochemical system (AFMSRX rotator, and AFCBP1 bipotentiostat). The RRDE electrode consisted of a catalyst-coated GC disk (5 mm diameter, $0.196 \mathrm{~cm}^{2}$ of geometric surface area) surrounded by a Pt ring $\left(0.125 \mathrm{~cm}^{2}\right.$ of geometric surface area). The electrochemical measurements were conducted in a standard three-electrode electrochemical cell at room temperature. A Pt-foil was used as the counter electrode, and a $\mathrm{Ag} / \mathrm{AgCl}$ (3 $\mathrm{M} \mathrm{Cl}^{-}$, Cypress) reference electrode was used in a double-junction reference chamber. The electrolyte was $0.1 \mathrm{M} \mathrm{KOH}$ solution prepared from ultrapure water (Millipore, 18.2 $\mathrm{M} \Omega \mathrm{cm}$ ). The working electrodes were the catalyst film-coated GC disks mounted on a disk-interchangeable rotating disk electrode (RDE, Pine Instruments).

The electrolyte was deaerated by purging high-purity Ar gas into the electrolyte for at least $30 \mathrm{~min}$ before each electrochemical measurement. The samples on the GC disks were first electrochemically cleaned by sweeping the potential in the range between -0.9 and $0 \mathrm{~V}(v s$. $\mathrm{Ag} / \mathrm{AgCl})$ at $50 \mathrm{mV} \mathrm{s}^{-1}$ in an $\mathrm{Ar}$ saturated $0.1 \mathrm{M} \mathrm{KOH}$ solution until steady state cyclic voltammograms (CV) were obtained. For each catalyst tested, a CV was first collected in Ar-saturated 0.1 $\mathrm{M} \mathrm{KOH}$ solution from -0.9 to $0 \mathrm{~V}$ at $10 \mathrm{mV} \mathrm{s}^{-1}$ to determine the non-Faradaic current.

For the ORR test, the electrolyte was purged with high-purity $\mathrm{O}_{2}$ gas for at least $30 \mathrm{~min}$ to ensure $\mathrm{O}_{2}$ saturation. Linear sweep voltammetry (LSV) measurements during oxygen reduction were performed in $\mathrm{O}_{2}$-saturated $0.1 \mathrm{M} \mathrm{KOH}$ by sweeping the potential from $-0.9 \mathrm{~V}$ anodically to $0 \mathrm{~V}$ at $10 \mathrm{mV} \mathrm{s}^{-1}$ with the electrode rotated at 400, 900, 1600 and $2500 \mathrm{rpm}$, and $\mathrm{O}_{2}$ gas purged into the solution at a flow rate of $25 \mathrm{sccm}$ through a 
$2 \mu \mathrm{m}$ fritted tube (Ace Glass). The faradaic current density, i.e., the current due to the oxygen reduction alone, was obtained by subtracting the capacitive current (the current measured from the CV under Ar) from the ORR data and then normalized by the geometric surface area,

$$
j=-\left(j_{\mathrm{ORR}}-j_{\text {capacitive,Ar-CV }}\right) / \mathrm{SA}_{\mathrm{geo}}
$$

The kinetic current density for the ORR was derived from the Koutecky-Levich equation:

$$
1 / j=1 / j_{\mathrm{k}}+1 / j_{\mathrm{d}}=1 / j_{\mathrm{k}}+1 /\left(B \omega^{1 / 2}\right)
$$

where, $j$ is the measured disk current density; $j_{\mathrm{k}}$ and $j_{\mathrm{d}}$ are the kinetic and diffusion limiting current densities, respectively; $B$ is the so-called " $B$-factor", which is given by the following equation:

$$
B=0.62 n F D_{\mathrm{O}_{2}}^{2 / 3} v^{-1 / 6} C_{\mathrm{O}_{2}}
$$

where, $n$ is the apparent number of electrons transferred in the reaction, $F$ is the Faraday constant (96485 $\mathrm{C} \mathrm{mol}^{-1}$ ), $D_{\mathrm{O}_{2}}$ is the diffusion coefficient of $\mathrm{O}_{2}\left(D_{\mathrm{O}_{2}}=1.86 \times 10^{-5} \mathrm{~cm}^{2} \mathrm{~s}^{-1}\right), v$ is the kinetic viscosity of the solution $\left(v=0.01 \mathrm{~cm}^{2} \mathrm{~s}^{-1}\right), C_{\mathrm{O}_{2}}$ is the concentration of $\mathrm{O}_{2}$ dissolved in the electrolyte $\left(C_{\mathrm{O}_{2}}=1.21 \times\right.$ $\left.10^{-6} \mathrm{~mol} \mathrm{~cm}^{-3}\right),{ }^{33,34}$ and $\omega$ is the electrode rotation speed. The ohmic resistances in the electrode contacts and electrolyte solution were assumed to be the same for the samples and were not included in the corrections.

For all the RRDE measurements, the ring potential was held at $0.5 \mathrm{~V}$ vs. $\mathrm{Ag} / \mathrm{AgCl}$ in order to oxidize any $\mathrm{H}_{2} \mathrm{O}_{2}$ produced in alkaline solution. ${ }^{35}$ The $\% \mathrm{HO}_{2}{ }^{-}$produced in alkaline solution was calculated using the following equation..$^{36-38}$

$$
\% \mathrm{HO}_{2}{ }^{-}=100 \frac{2 I_{\mathrm{R}} / \mathrm{N}}{I_{\mathrm{D}}+\left(I_{\mathrm{R}} / \mathrm{N}\right)}
$$

where, $I_{\mathrm{D}}$ is the Faradaic current at the disk, $I_{\mathrm{R}}$ is the Faradaic current at the ring, and $N=0.22$ is the disk electrode collection efficiency.

\section{Results and discussion}

\subsection{Structure of $\mathbf{P}(\mathrm{Co})-\mathrm{C}$}

Fig. 1 shows the X-ray diffraction $(\mathrm{XRD})$ profile of the $\mathrm{P}(\mathrm{Co})-\mathrm{C}$, the XRD profiles of pure carbon $(\mathrm{C}), \mathrm{Co}-\mathrm{C}$ and $\mathrm{P}-\mathrm{C}$ are also included for comparison. All the samples show two obvious diffraction peaks at $2 \theta=24^{\circ}$ and $43.7^{\circ}$ that can be corresponded to (002) and (100) reflections of the carbon phase, respectively. For the Co-C sample, the (002) diffraction peak becomes sharp and the intensity of the (100) diffraction peak is also enhanced to some extent, indicating the positive effect of Co on the graphitization of carbon. The Co phase can be observed clearly in the Co-C sample. No other phases other than carbon are observed in the $\mathrm{P}(\mathrm{Co})-\mathrm{C}$ sample.

To further confirm the structure of the as-synthesized $\mathrm{P}(\mathrm{Co})-$ $\mathrm{C}$, a Raman spectrometer was used to study the structure. The comparison between the Raman spectroscopy of $\mathrm{C}, \mathrm{Co}-\mathrm{C}, \mathrm{P}-\mathrm{C}$ and $\mathrm{P}(\mathrm{Co})-\mathrm{C}$ is shown in Fig. 2. There are two peaks centered at

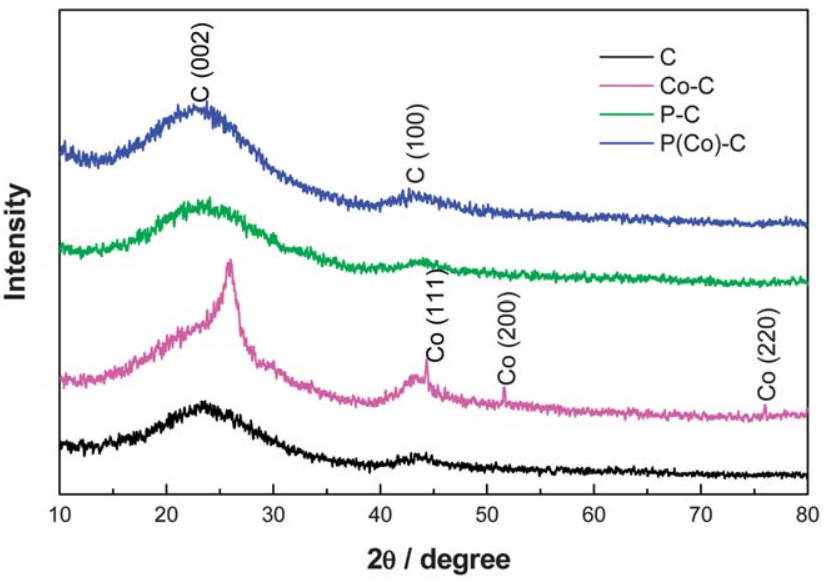

Fig. 1 XRD patterns of $C, C O-C, P-C$ and $P(C O)-C$. Bragg peaks positions for the phase $\mathrm{Co}$ in $\mathrm{Co}-\mathrm{C}$ have been indicated.

approximately $1580 \mathrm{~cm}^{-1}$ and $1352 \mathrm{~cm}^{-1}$, which are the G-band and D-band, respectively. The ratio of intensities for the D-band and G-band $\left(I_{\mathrm{D}} / I_{\mathrm{G}}\right)$ is generally used as a measure for the degree of defect of the carbon. ${ }^{39}$ As shown in Fig. 2, the $I_{\mathrm{D}} / I_{\mathrm{G}}$ of the prepared pure carbon is 0.90 and it decreases to 0.86 for $\mathrm{Co}-\mathrm{C}$, indicating the effect of Co on the graphitization of carbon. In contrast, the $I_{\mathrm{D}} / I_{\mathrm{G}}$ increases to 1.13 for $\mathrm{P}-\mathrm{C}$ and 0.98 for $\mathrm{P}(\mathrm{Co})-$ $\mathrm{C}$, which suggests that the heteroatom $\mathrm{P}$ doping in the carbon develops defect sites. This agrees well with the results from the XRD. It is important to note that the $I_{\mathrm{D}} / I_{\mathrm{G}}$ value of $\mathrm{P}(\mathrm{Co})-\mathrm{C}(0.98)$ is lower than that of $\mathrm{P}-\mathrm{C}$ (1.13), which suggests that less defects are introduced in $\mathrm{P}(\mathrm{Co})-\mathrm{C}$ due to graphitization of carbon induced by Co during the preparation of $\mathrm{P}(\mathrm{Co})-\mathrm{C}$. The formation of graphitic structures takes place during the heat treatment step through a mechanism that involves the dissolution of amorphous carbon into Co catalyst particles followed by the precipitation of graphitic carbon. ${ }^{\mathbf{4 0 - 4 5}}$

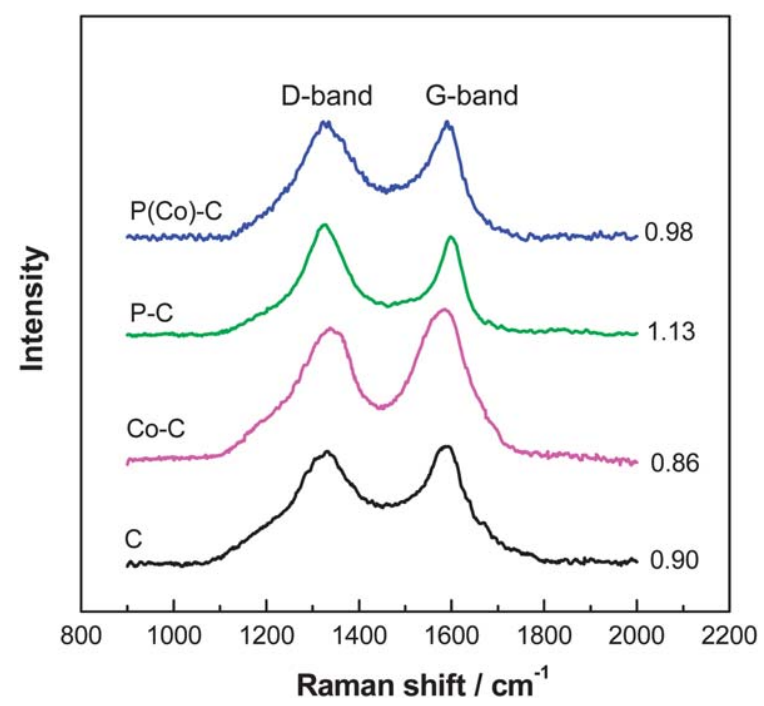

Fig. 2 The D-band and G-band in Raman spectroscopy for C, Co-C, P-C and $\mathrm{P}(\mathrm{Co})-\mathrm{C}$. The ratio of $\mathrm{D}$-band to $\mathrm{G}$-band $\left(I_{\mathrm{D}} / /_{\mathrm{G}}\right)$ is indicated for each sample. 

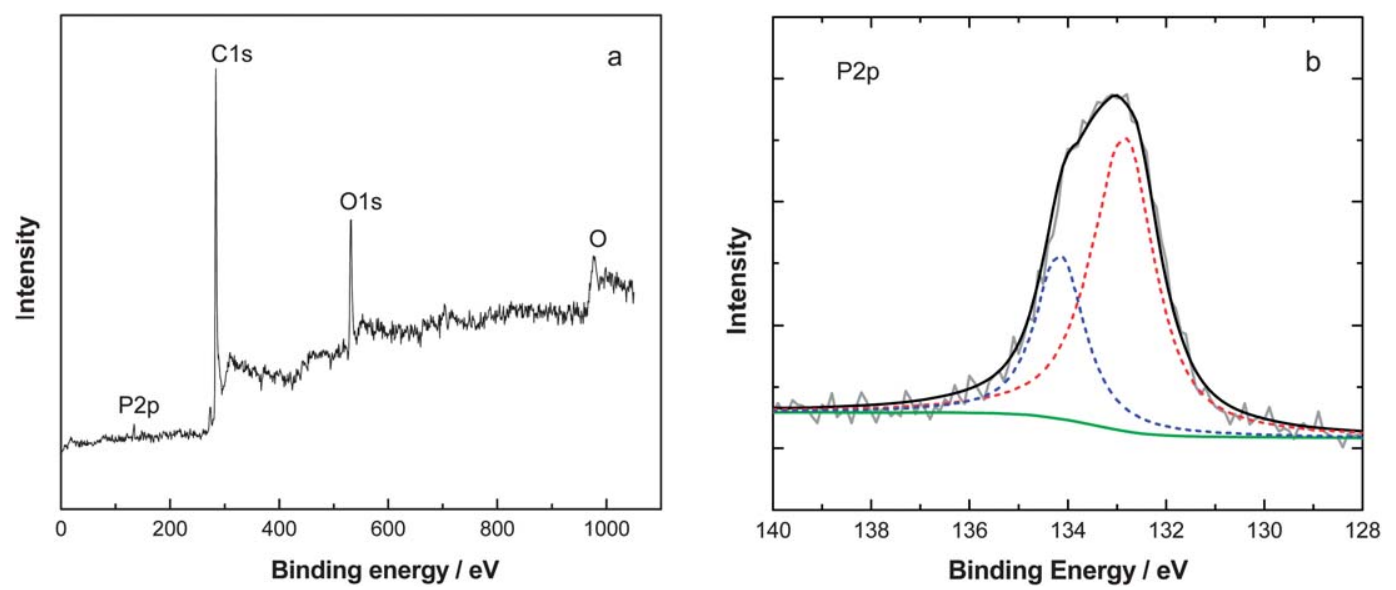

Fig. 3 (a)XPS survey spectra of $P(C o)-C$; and (b) XPS spectra for the $P$ 2p peak of $P(C o)-C$.

The binding environment of $\mathrm{P}$ in the $\mathrm{P}(\mathrm{Co})-\mathrm{C}$ sample is elucidated by X-ray photoelectron spectroscopy (XPS). As expected, the XPS survey spectrum given in Fig. 3a shows the C 1s, O 1s, and P 2p peaks for the $\mathrm{P}(\mathrm{Co})-\mathrm{C}$ sample. The $\mathrm{O} 1 \mathrm{~s}$ peak most likely arises from the incorporation of physicochemically adsorbed oxygen. The absence of any Co peak in the XPS survey spectrum confirms that the residual cobalt has been completely removed by acid wash. The detailed P $2 p$ scan is depicted in Fig. 3b. Two deconvoluted contributions appear at $134.25 \mathrm{eV}$ and $132.51 \mathrm{eV}$. The value of $134.25 \mathrm{eV}$ has been observed for $\mathrm{P}$ in high oxidation states, ${ }^{46}$ referring to surface oxidised P species. The other one, a dominant phase, is controversially discussed in many papers, ${ }^{24,28,46,47}$ but the most comprehensive explanation is the contribution at $132.51 \mathrm{eV}$ is attributed to $\mathrm{P}-\mathrm{C}$ binding..$^{22,44,45}$ This reveals that the $\mathrm{P}$ atom has been incorporated into the carbon lattice.

P-doping can also affect the surface area and pore size of the carbon. Fig. 4 shows the nitrogen adsorption isotherms and pore size distributions of the $\mathrm{C}, \mathrm{Co}-\mathrm{C}, \mathrm{P}-\mathrm{C}$ and $\mathrm{P}(\mathrm{Co})-\mathrm{C}$. The determined BET surface areas, micropore volumes and average pore sizes of all investigated samples are summarized in Table 1. The nitrogen adsorption isotherms of all prepared samples (Fig. 4a) correspond to type-I isotherms according to the classification of the International Union of Pure and Applied Chemistry (IUPAC), which is the characteristic feature of a microporous material. The carbon exhibits $773.6 \mathrm{~m}^{2} \mathrm{~g}^{-1}$ of BET specific surface area, after being loaded with Co (i.e. Co-C), the area decreases to $729.3 \mathrm{~m}^{2} \mathrm{~g}^{-1}$. But after P-doping, the area increases to 1320.5 and $1349.2 \mathrm{~m}^{2} \mathrm{~g}^{-1}$ for $\mathrm{P}-\mathrm{C}$ and $\mathrm{P}(\mathrm{Co})-\mathrm{C}$, respectively. The average pore width is $0.65 \mathrm{~nm}$ for carbon and $0.64 \mathrm{~nm}$ for $\mathrm{Co}-\mathrm{C}$, it slightly increases to 0.67 and $0.68 \mathrm{~nm}$ for $\mathrm{P}-\mathrm{C}$ and $\mathrm{P}(\mathrm{Co})-\mathrm{C}$, respectively. The micropore volume is $0.46 \mathrm{~m}^{3}$ $\mathrm{g}^{-1}$ for carbon and $0.42 \mathrm{~m}^{3} \mathrm{~g}^{-1}$ for $\mathrm{Co}-\mathrm{C}$, and it increases to 0.63 and $0.61 \mathrm{~m}^{3} \mathrm{~g}^{-1}$ for $\mathrm{P}-\mathrm{C}$ and $\mathrm{P}(\mathrm{Co})-\mathrm{C}$, respectively. The increases in the specific surface area of $\mathrm{P}-\mathrm{C}$ and $\mathrm{P}(\mathrm{Co})-\mathrm{C}$ may result from P-doping as well as phosphoric acid activation since phosphoric acid is an activating agent for the carbon activation. $^{48,49}$ The increases in the average pore size and the micropore volume in $\mathrm{P}-\mathrm{C}$ and $\mathrm{P}(\mathrm{Co})-\mathrm{C}$ are most likely due to the enlargement of micropores and the etching on the carbon framework by the phosphoric acid treatment. Moreover, as shown in the SEM images (Fig. 5), the surface of Co-C is smooth (Fig. 5a). In contrast, the surfaces of P-C (Fig. 5b) and $\mathrm{P}(\mathrm{Co})-\mathrm{C}$ (Fig. 5c) are rough due to the treatment with phosphoric acid,
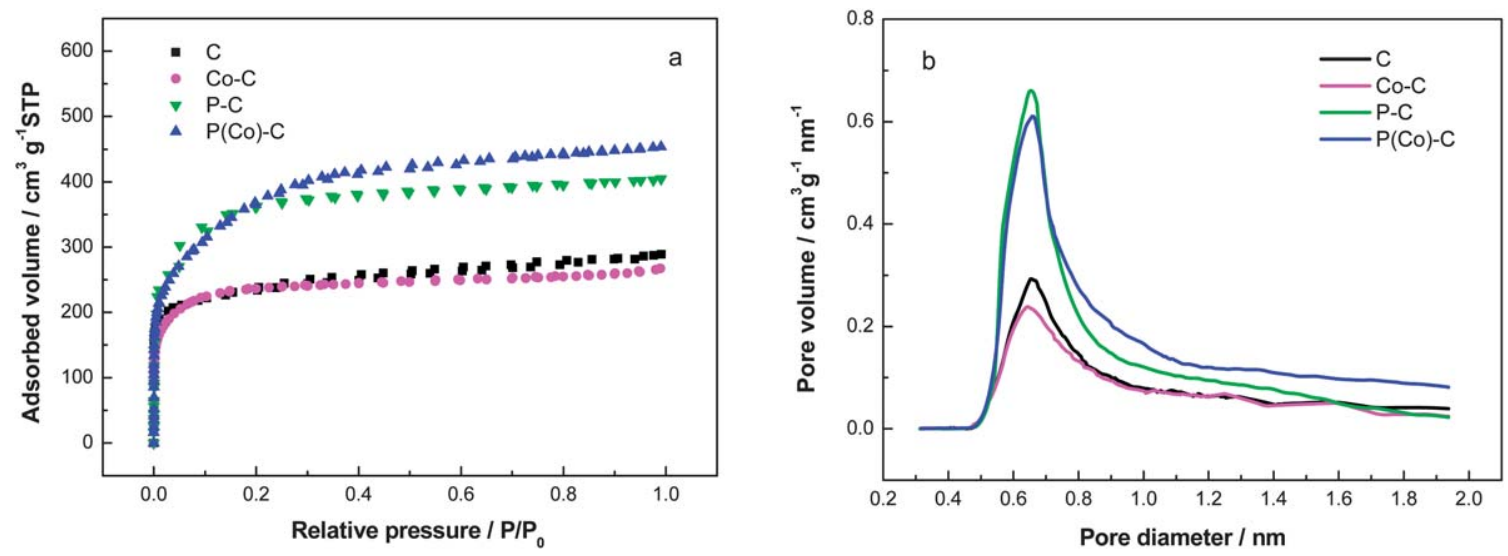

Fig. 4 BET surface areas (a) and pore size distributions (b) for $C, C o-C, P-C$ and $P(C o)-C$. 
Table 1 BET surface area, total micropore volume and average pore size of the samples

\begin{tabular}{llll}
\hline Samples & $\begin{array}{l}\text { BET surface } \\
\text { area } / \mathrm{m}^{2} \mathrm{~g}^{-1}\end{array}$ & $\begin{array}{l}\text { Total micropore } \\
\text { volume } / \mathrm{m}^{3} \mathrm{~g}^{-1}\end{array}$ & $\begin{array}{l}\text { Average pore } \\
\text { size } / \mathrm{nm}\end{array}$ \\
\hline $\mathrm{C}$ & 773.6 & 0.46 & 0.65 \\
$\mathrm{Co}-\mathrm{C}$ & 729.3 & 0.42 & 0.64 \\
$\mathrm{P}-\mathrm{C}$ & 1320.5 & 0.63 & 0.67 \\
$\mathrm{P}(\mathrm{Co})-\mathrm{C}$ & 1349.2 & 0.61 & 0.68 \\
\hline
\end{tabular}

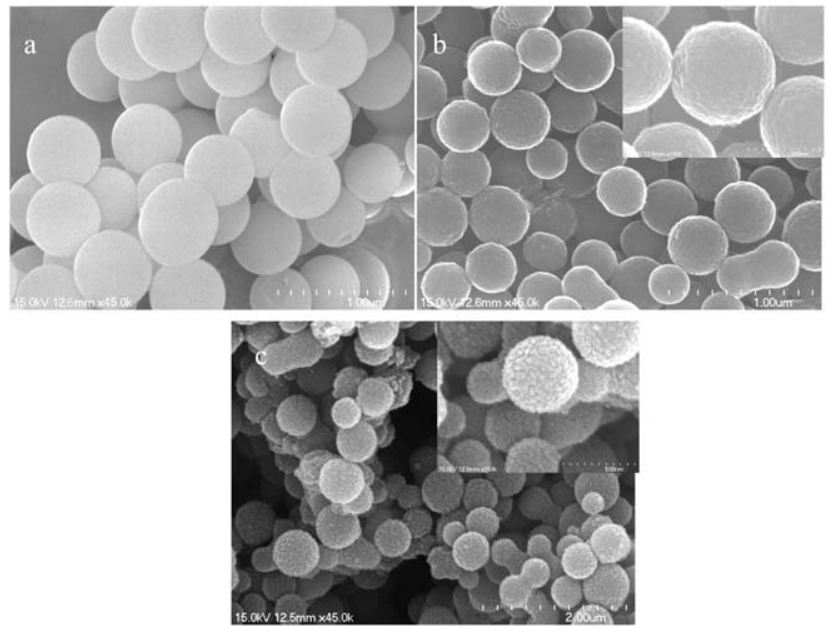

Fig. 5 SEM images of $\mathrm{Co}-\mathrm{C}(\mathrm{a}), \mathrm{P}-\mathrm{C}(\mathrm{b})$, and $\mathrm{P}(\mathrm{Co})-\mathrm{C}(\mathrm{c})$.

which are consistent with the BET surface areas of these samples $\left(729.3 \mathrm{~m}^{2} \mathrm{~g}^{-1}\right.$ for $\mathrm{Co}-\mathrm{C}, 1320.5 \mathrm{~m}^{2} \mathrm{~g}^{-1}$ for $\mathrm{P}-\mathrm{C}$ and $1349.2 \mathrm{~m}^{2} \mathrm{~g}^{-1}$ for $\left.\mathrm{P}(\mathrm{Co})-\mathrm{C}\right)$. The results show that the doping of carbon/activation of the carbon with phosphoric acid and surface roughening would increase the surface area of the carbon.

The surface $\mathrm{P}$ content in $\mathrm{P}(\mathrm{Co})-\mathrm{C}$ is determined to be 1.60 atom\%, which is lower than the bulk $\mathrm{P}$ content (1.73 atom\%) as measured from ICP. In contrast, the surface P content (1.84 atom\%) is similar to the bulk P content (1.89 atom\%) in P-C. The lower $\mathrm{P}$ content at the surface of $\mathrm{P}(\mathrm{Co})-\mathrm{C}$ might result from some $\mathrm{P}$ bonding with Co during the preparation of $\mathrm{P}(\mathrm{Co})-\mathrm{C}$, which were removed along with Co after acid wash. This is also supported by the fact that the $\mathrm{P}$ content (both surface and bulk) in $\mathrm{P}(\mathrm{Co})-\mathrm{C}$ is lower than that in $\mathrm{P}-\mathrm{C}$ prepared with the same method.

\subsection{Catalytic activity of $\mathbf{P}(\mathrm{Co})-\mathrm{C}$ for oxygen reduction}

Cyclic voltammetry (CV) of a typical $\mathrm{P}(\mathrm{Co})-\mathrm{C}$ on $\mathrm{GC}$ disks in 0.1 $\mathrm{M} \mathrm{KOH}$ is shown in Fig. 6, which is compared with pure $\mathrm{C}$, Co-C and $\mathrm{P}-\mathrm{C}$. The $\mathrm{CV}$ s of $\mathrm{P}-\mathrm{C}$ and $\mathrm{P}(\mathrm{Co})-\mathrm{C}$ resemble that of pure $\mathrm{C}$. The redox peaks that appear in the potential regions of -0.1 to $0.1 \mathrm{~V}$ and -0.6 to $-0.4 \mathrm{~V}$ of $\mathrm{Co}-\mathrm{C}$ correspond to the oxidation and reduction of $\mathrm{Co}^{50}$ The $\mathrm{CV}$ area is related to the capacitance of the sample..$^{51}$ It can be seen that the CV area from the electrochemical double layer does not change much for $\mathrm{Co}-\mathrm{C}$ as compared with pure C. In contrast, the $\mathrm{CV}$ areas for both $\mathrm{P}-\mathrm{C}$

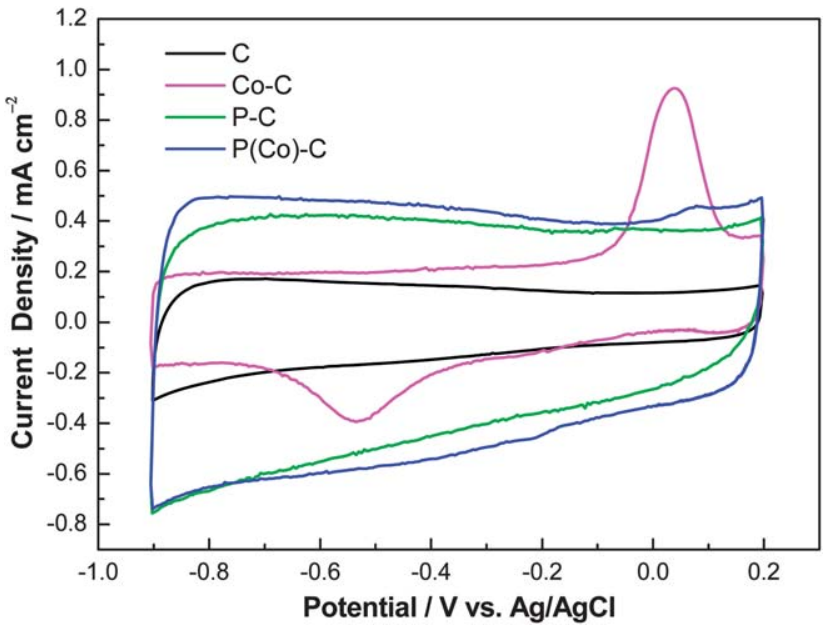

Fig. 6 Cyclic voltammograms of $\mathrm{C}, \mathrm{Co}-\mathrm{C}, \mathrm{P}-\mathrm{C}$ and $\mathrm{P}(\mathrm{CO})-\mathrm{C}$. Experiments were conducted in Ar-saturated $0.1 \mathrm{M} \mathrm{KOH}$ at $298 \mathrm{~K}$ with a sweep rate of $10 \mathrm{mV} \mathrm{s}^{-1}$.

and $\mathrm{P}(\mathrm{Co})-\mathrm{C}$ samples increased as compared with pure $\mathrm{C}$. The increase in the $\mathrm{CV}$ areas (i.e. capacitance) for $\mathrm{P}-\mathrm{C}$ and $\mathrm{P}(\mathrm{Co})-\mathrm{C}$ samples is consistent with the increase in the specific surface areas of these two samples as shown in Fig. 4 and Table 1.

To better understand the electrocatalytic performance of the $\mathrm{P}(\mathrm{Co})-\mathrm{C}$ catalysts during the ORR process, the comparison between the ORR activities on $\mathrm{P}(\mathrm{Co})-\mathrm{C}, \mathrm{P}-\mathrm{C}, \mathrm{Co}-\mathrm{C}$ and pure $\mathrm{C}$ as measured with the RRDE is shown in Fig. 7. The ORR activity on commercial Pt/C is also included for comparison. The disk and ring currents shown were measured at $1600 \mathrm{rpm}$ and normalized by the geometric surface area. The ORR activity increases as follows: $\mathrm{C}<\mathrm{Co}-\mathrm{C}<\mathrm{P}-\mathrm{C}<\mathrm{P}(\mathrm{Co})-\mathrm{C}$, as evidenced by the diffusion limiting current densities and the onset potentials of these samples (Fig. 7a). The diffusion limiting current density of $\mathrm{P}(\mathrm{Co})-\mathrm{C}$ reaches that of $\mathrm{Pt} / \mathrm{C}$ and a negative shift of about $72 \mathrm{mV}$ exists in the half-wave potential of $\mathrm{P}(\mathrm{Co})-\mathrm{C}$ as compared to $\mathrm{Pt} / \mathrm{C}$. It should be noted that the diffusion limiting current density and half-wave potential of the $\mathrm{Pt} / \mathrm{C}$ are in good agreement with the values of $\mathrm{Pt} / \mathrm{C}(20 \mathrm{wt} \% \mathrm{Pt})$ reported elsewhere. ${ }^{52,53}$ This clearly shows that $\mathrm{P}(\mathrm{Co})-\mathrm{C}$ is more active than $\mathrm{P}-\mathrm{C}, \mathrm{Co}-\mathrm{C}$ and pure $\mathrm{C}$ and is comparable to the activity of $\mathrm{Pt} / \mathrm{C}$. To verify the ORR catalytic pathways of the catalysts, the formation of peroxide species $\left(\mathrm{HO}_{2}^{-}\right)$during the ORR process was monitored with rotating ring-disk electrode (RRDE) measurements (Fig. 7b). The measured $\mathrm{HO}_{2}{ }^{-}$yields on the catalysts increase as follows: $\mathrm{P}(\mathrm{Co})-\mathrm{C}<\mathrm{P}-\mathrm{C}<\mathrm{Co}-\mathrm{C}<\mathrm{C}$, the corresponding electron number transferred during the ORR reaction increases in the reverse order. The measured $\mathrm{HO}_{2}{ }^{-}$yields are below $\sim 13 \%$ for $\mathrm{P}(\mathrm{Co})-\mathrm{C}$ over the potential range of -0.80 to $-0.30 \mathrm{~V}$, giving an electron transfer number of $3.72-3.79$. This is comparable to $\mathrm{Pt} / \mathrm{C}, \mathrm{HO}_{2}{ }^{-}$yields for which are below $\sim 8 \%$ and the electron transfer number for which is 3.90-3.96 (Fig. 7b). These results indicate that $\mathrm{P}$ doping in the carbon prepared in the presence of Co can significantly improve the catalytic activity of carbon. Importantly, P-doped carbon alone (i.e. P-C) exhibits lower ORR activity than P-doped carbon prepared in the presence of Co (i.e. $\mathrm{P}(\mathrm{Co})-\mathrm{C})$. This suggests that Co plays an important role in improving the catalytic activity of P-doped carbon. 

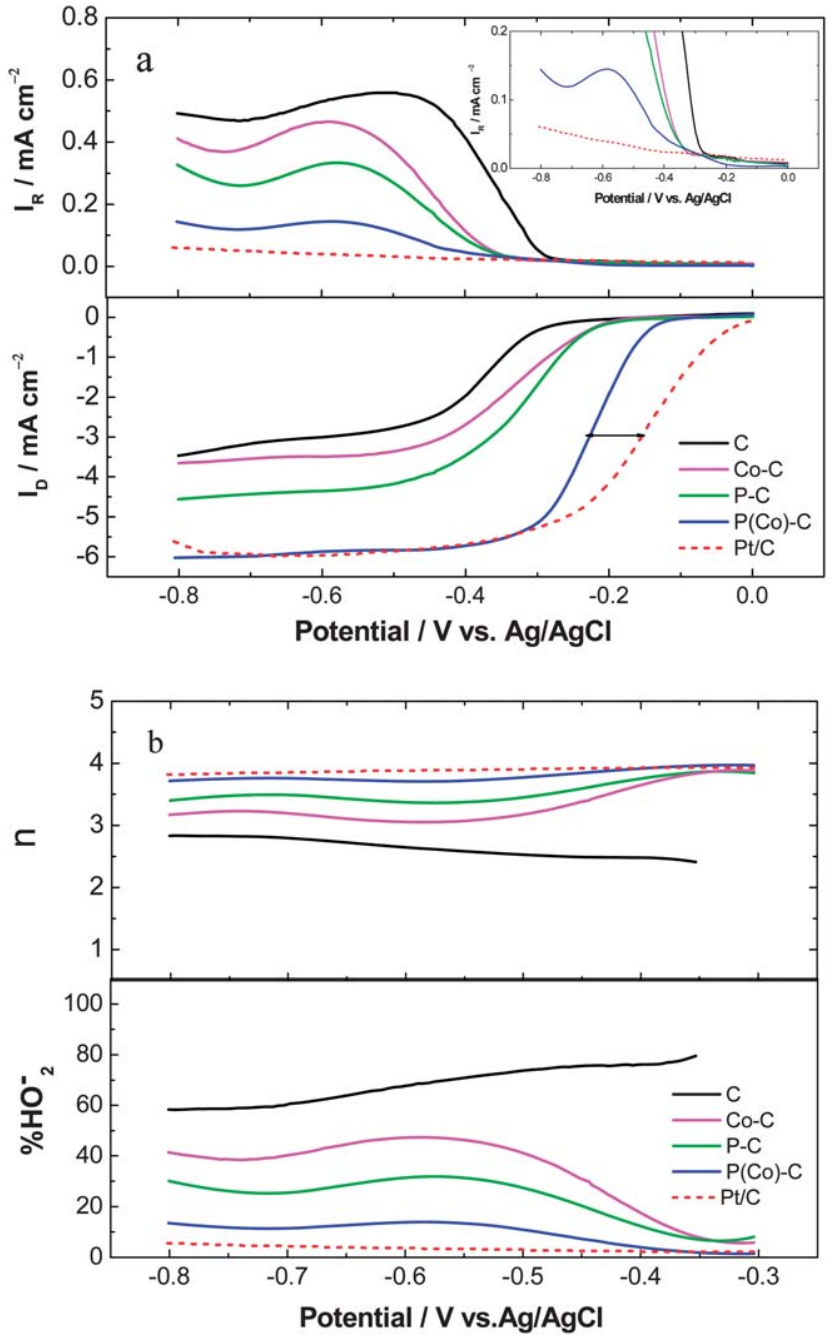

Fig. 7 (a) Linear sweeping voltammograms (LSVs) on the rotating ring-disk electrode for $\mathrm{C}, \mathrm{Co}-\mathrm{C}, \mathrm{P}-\mathrm{C}, \mathrm{P}(\mathrm{Co})-\mathrm{C}$ and commercial $\mathrm{Pt} / \mathrm{C}$ in $\mathrm{O}_{2}$-saturated $0.1 \mathrm{M}$ $\mathrm{KOH}$ at a rotating speed of $1600 \mathrm{rpm}$. The disk potential was scanned at $10 \mathrm{mV}$ $\mathrm{s}^{-1}$ and the ring potential was fixed at $0.5 \mathrm{~V}$. (b) Calculated electron transfer number $(n)$ and determined peroxide percentage at various potentials based on the corresponding RRDE data in (a).

The diffusion-current-corrected Tafel plots of specific ORR activity of these samples are shown in Fig. 8 . To construct the Tafel plots, the kinetic currents were derived from the masstransport correction using eqn (2). At low over-potentials,

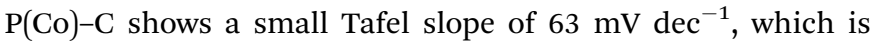
close to that of $\mathrm{Pt} / \mathrm{C}\left(69 \mathrm{mV} \mathrm{dec}{ }^{-1}\right)$ and approaches the theoretical value of $2.303 R T / F$ (i.e., $59 \mathrm{mV} \mathrm{dec}{ }^{-1}$ at $25^{\circ} \mathrm{C}$ ), where $R$ is the universal gas constant, $F$ is the Faraday constant, and $T$ is the absolute temperature. The Tafel slope of $\mathrm{P}(\mathrm{Co})-\mathrm{C}$ is also smaller than that of $\mathrm{P}-\mathrm{C}\left(75 \mathrm{mV} \mathrm{dec}{ }^{-1}\right), \mathrm{Co}-\mathrm{C}\left(72 \mathrm{mV} \mathrm{dec}^{-1}\right)$ and pure $\mathrm{C}\left(77 \mathrm{mV} \mathrm{dec}^{-1}\right)$. The low Tafel slope indicates the high intrinsic catalytic activity of $\mathrm{P}(\mathrm{Co})-\mathrm{C}$.

The polarization curves for the ORR on $\mathrm{P}(\mathrm{Co})-\mathrm{C}$ at different rotation rates are shown in Fig. 9a. They all reached well-defined diffusion limiting currents. Fig. $9 \mathrm{~b}$ shows the corresponding Koutecky-Levich plots obtained from the inverse current density $\left(j^{-1}\right)$ as a function of the inverse of the square root of the

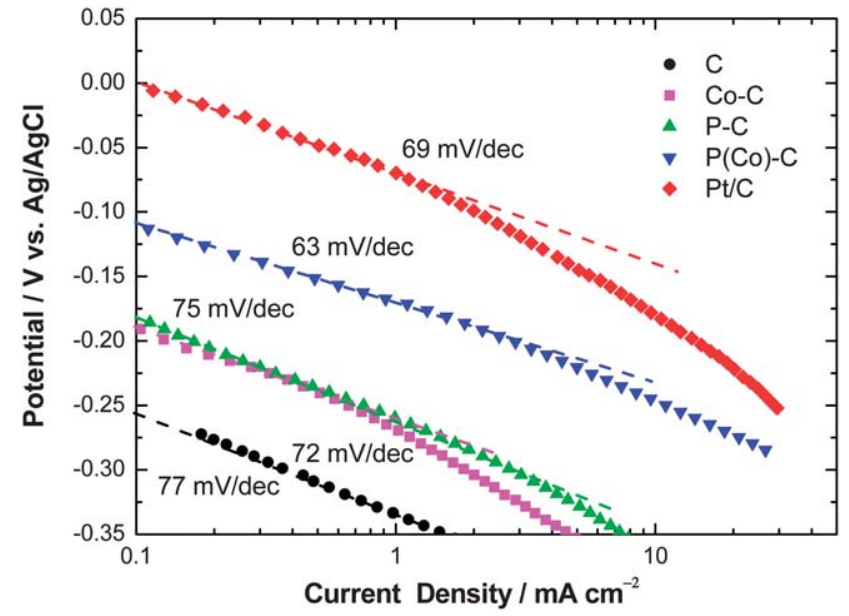

Fig. 8 Tafel plots of $\mathrm{C}, \mathrm{Co}-\mathrm{C}, \mathrm{P}-\mathrm{C}, \mathrm{P}(\mathrm{Co})-\mathrm{C}$ and commercial Pt/C derived by the mass transport correction of corresponding LSV data recorded in $\mathrm{O}_{2}$-saturated $0.1 \mathrm{M} \mathrm{KOH}$ with a sweeping rate of $10 \mathrm{mV} \mathrm{s}^{-1}$ and a rotating speed of $1600 \mathrm{rpm}$.
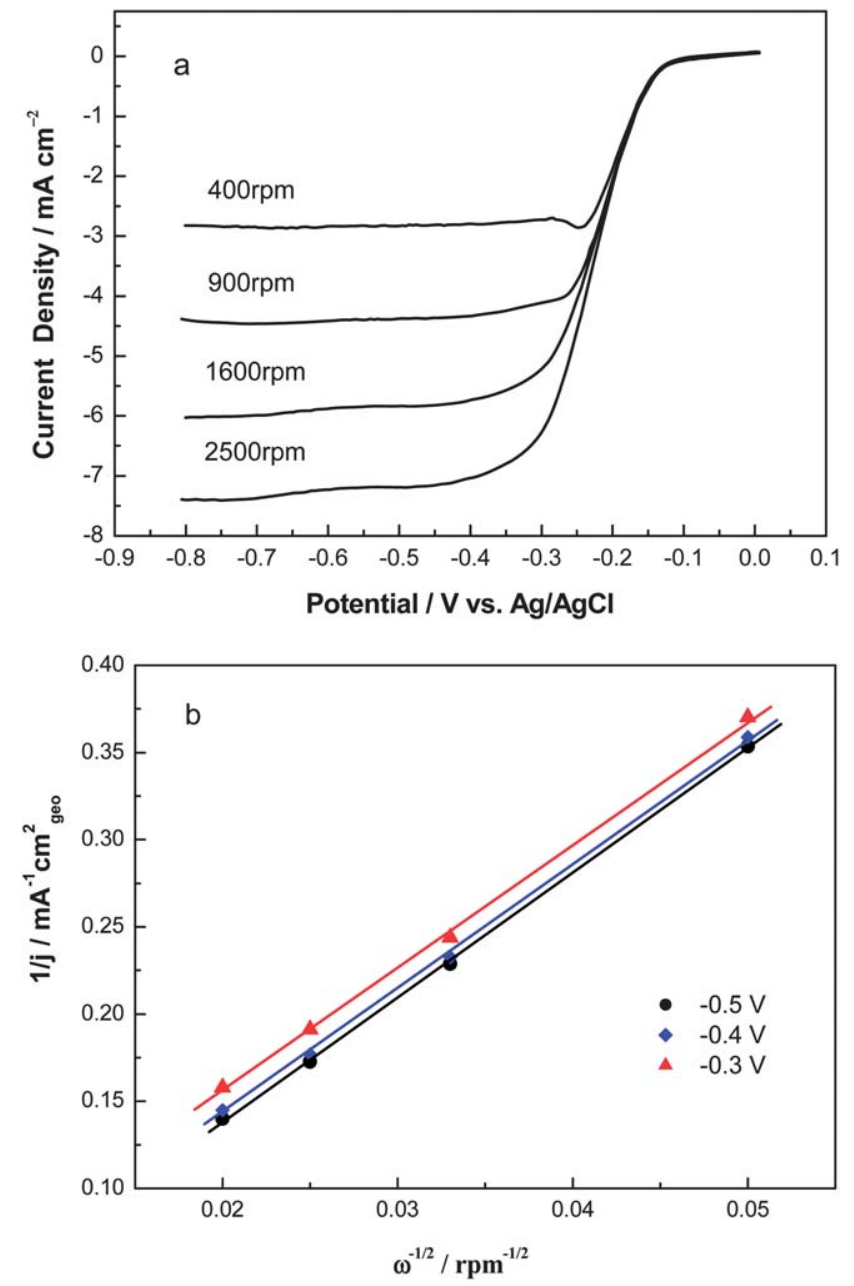

Fig. 9 (a) LSVs of $\mathrm{P}(\mathrm{Co})-\mathrm{C}$ in $\mathrm{O}_{2}$-saturated $0.1 \mathrm{M} \mathrm{KOH}$ with a scan rate of $10 \mathrm{mV}$ $\mathrm{s}^{-1}$ at different electrode rotating speeds. (b) Koutecky-Levich plots for the ORR in $\mathrm{O}_{2}$-saturated $0.1 \mathrm{M} \mathrm{KOH}$ solution for $\mathrm{P}(\mathrm{CO})-\mathrm{C}$. 
rotation rate $\left(\omega^{-1 / 2}\right)$ for $\mathrm{P}(\mathrm{Co})-\mathrm{C}$ at $-0.30,-0.40$ and $-0.50 \mathrm{~V}$, respectively. These plots are linear and parallel, indicating the first-order dependence of the kinetics of the ORR on the $\mathrm{P}(\mathrm{Co})-$ C surface. Each straight line intercept corresponds to the kinetic current $i_{\mathrm{k}}$. The " $B$-factor" for $\mathrm{P}(\mathrm{Co})-\mathrm{C}$ is $0.143 \mathrm{~mA} \mathrm{~cm}{ }^{-2}$ $\omega^{-1 / 2}$, determined from the slope of Koutecky-Levich plots. The electron number calculated from the $B$-factor is $\sim 3.78$. This is consistent with the result $(n \approx 3.72-3.79$ ) obtained from the RRDE measurements, suggesting that the ORR reactions on the surface of $\mathrm{P}(\mathrm{Co})-\mathrm{C}$ proceed mainly with the $n=4 \mathrm{e}^{-}$reaction pathway.

The durability of $\mathrm{P}(\mathrm{Co})-\mathrm{C}$ and the commercial $\mathrm{Pt} / \mathrm{C}$ was checked by running CVs for 2000 cycles as shown in Fig. 10. The ORR current density of the $\mathrm{P}(\mathrm{Co})-\mathrm{C}$ catalyst at $-0.6 \mathrm{~V}$ decreases by $12.0 \%$ after 2000 repeated cycles, while a decrease of $19.6 \%$ in current density is observed for the $\mathrm{Pt} / \mathrm{C}$ catalyst. This reveals that the $\mathrm{P}(\mathrm{Co})-\mathrm{C}$ has good long-term performance, which might result from the strong covalent bond between $\mathrm{C}$ and $\mathrm{P}$ as well as the absence of metal (like Pt) agglomeration and migration, an important factor accounting for the degradation of the $\mathrm{Pt} / \mathrm{C}$ catalyst.

The results show that the $\mathrm{P}$-doped porous carbon (i.e. $\mathrm{P}(\mathrm{Co})-$ C) prepared in the presence of Co exhibits high catalytic activity for the ORR. Co introduced during the preparation of the samples plays an important role in improving the activity of P-doped carbon even though Co does not exist in the final sample. The $\mathrm{P}(\mathrm{Co})-\mathrm{C}$ and $\mathrm{P}-\mathrm{C}$ show higher activity than pure carbon and $\mathrm{Co}-\mathrm{C}$, indicating the critical effect of P-doping on the improvement of the catalytic activity of carbon for the ORR. The high surface areas $\left(1320.5 \mathrm{~m}^{2} \mathrm{~g}^{-1}\right.$ for the $\mathrm{P}-\mathrm{C}$ and $1349.2 \mathrm{~m}^{2}$ $\mathrm{g}^{-1}$ for the $\left.\mathrm{P}(\mathrm{Co})-\mathrm{C}\right)$ are also important for the high activity of $\mathrm{P}(\mathrm{Co})-\mathrm{C}$ and $\mathrm{P}-\mathrm{C}$ since high edge exposure can be induced with the high surface area of the samples. The higher activity of $\mathrm{P}(\mathrm{Co})-\mathrm{C}$ than that of $\mathrm{P}-\mathrm{C}$ is due to the fact that additional P-doping in the $\mathrm{P}-\mathrm{C}$ sample induces more defect sites as confirmed by the higher $I_{\mathrm{D}} / I_{\mathrm{G}}$ value (1.13), which could destroy the $\mathrm{sp}^{2}$-carbon network in the $\mathrm{P}-\mathrm{C}$ structure and reduce the

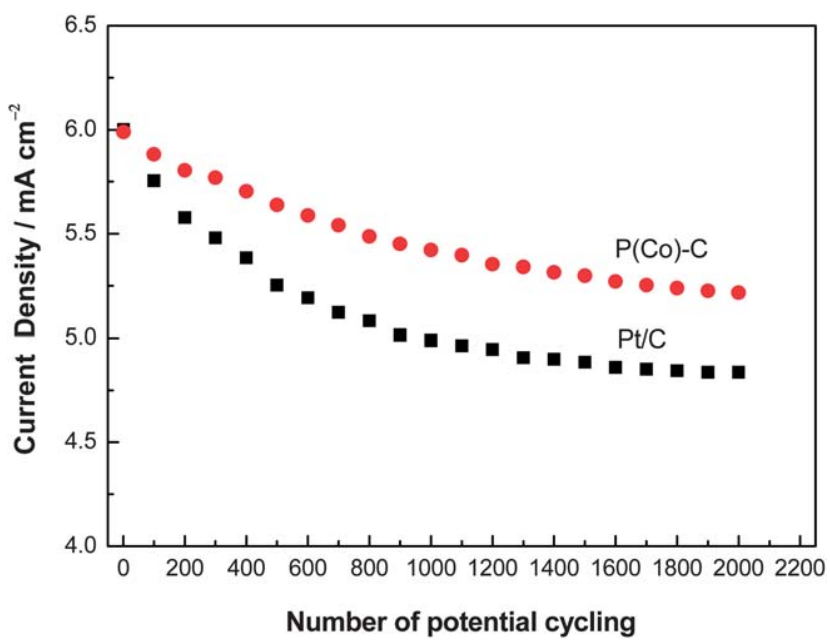

Fig. 10 Current density as a function of cycle number for $P(C O)-C$ and commercial Pt/C in $\mathrm{O}_{2}$-saturated $0.1 \mathrm{M} \mathrm{KOH}$ at a rotating speed of $1600 \mathrm{rpm}$. electrical conductivity of the carbon. ${ }^{51,54,55}$ For the $\mathrm{P}(\mathrm{Co})-\mathrm{C}$ sample, although Co was washed away in the final sample, Co could bond with $\mathrm{P}$ during the preparation of the sample and avoid too much doping of $\mathrm{P}$ into the carbon. Meanwhile, the electron transfer from Co to the carbon leads to a decreased local work function on the carbon surface, which favors the adsorption of $\mathrm{O}_{2}$ and the ORR as shown by the density functional theory (DFT) studies of Bao et al. ${ }^{56}$

\section{Conclusions}

In summary, the P-doped porous carbon (i.e. $\mathrm{P}(\mathrm{Co})-\mathrm{C}$ ) electrocatalysts were prepared by simultaneous doping and activation of carbon with phosphoric acid $\left(\mathrm{H}_{3} \mathrm{PO}_{4}\right)$ in the presence of Co. The $\mathrm{P}(\mathrm{Co})-\mathrm{C}$ showed high activities for the ORR in alkaline solutions, which is comparable to those of commercial Pt/C (20 wt $\%$ Pt on Vulcan XC-72, Johnson Matthey). The long-term stability of $\mathrm{P}(\mathrm{Co})-\mathrm{C}$ is superior to $\mathrm{Pt} / \mathrm{C}$. The ORR activity enhancement in $\mathrm{P}(\mathrm{Co})-\mathrm{C}$ arises from the $\mathrm{P}$ doping into the carbon lattice and the high surface area of the carbon induced by phosphoric acid activation. We find that Co introduced during the preparation of the sample also plays an important role in improving the ORR activity of P-doped carbon although Co was washed away in the final sample. The Co could bond with $\mathrm{P}$ during the preparation of the sample and avoid too much doping of $\mathrm{P}$ into the carbon, and also could transfer electron to the carbon leading to a decreased local work function on the carbon surface and therefore a high activity for the ORR.

\section{Acknowledgements}

This work is supported by the National Natural Science Foundation of China (no. 51272167 and 21206101), the Natural Science Foundation of the Higher Education Institutions of Jiangsu Province, China (12KJB430010).

\section{References}

1 M. S. Dresselhaus and I. L. Thomas, Nature, 2001, 414, 32.

2 P. G. Bruce, L. J. Hardwick and K. M. Abraham, MRS Bull., 2011, 36, 506.

3 M. Armand and J. M. Tarascon, Nature, 2008, 451, 652.

4 V. Neburchilov, H. J. Wang, J. J. Martin and W. Qu, J. Power Sources, 2010, 195, 1271.

5 R. R. Adzic, in Electrocatalysis, ed. J. Lipkowski and P. N. Ross, Wiley, New York, 1998, p. 197.

6 H. A. Gasteiger, S. S. Kocha, B. Sompalli and F. T. Wagner, Appl. Catal., B, 2005, 9, 56.

7 R. Z. Yang, J. Leisch, P. Strasser and M. Toney, Chem. Mater., 2010, 22, 4712.

8 F. Y. Cheng and J. Chen, Chem. Soc. Rev., 2012, 41, 2172.

9 R. Z. Yang, W. Y. Bian, P. Strasser and M. F. Toney, J. Power Sources, 2013, 222, 169.

10 M. Lefèvre, E. Proietti, F. Jaouen and J.-P. Dodelet, Science, 2009, 324, 71.

11 K. P. Gong, F. Du, Z. H. Xia, M. Durstock and L. M. Dai, Science, 2009, 323, 760. 
12 R. Liu, D. Wu, X. Feng and K. Müllen, Angew. Chem., Int. Ed., 2010, 49, 2565.

13 G. Wu, K. L. More, C. M. Johnston and P. Zelenay, Science, 2011, 332, 443.

14 Q. H. Yang, W. H. Xu, A. Tomita and T. Kyotani, Chem. Mater., 2005, 17, 2940.

15 L. P. Zhang and Z. H. Xia, J. Phys. Chem. C, 2011, 115, 11170.

16 V. V. Strelko, V. S. Kuts and P. A. Thrower, Carbon, 2000, 38, 1499.

17 S. Maldonado and K. J. Stevenson, J. Phys. Chem. B, 2004, 108, 11375.

18 Y. Y. Shao, J. H. Sui, G. P. Yin and Y. Z. Gao, Appl. Catal., B, 2008, 79, 89.

19 M. Zhang and L. Dai, Nano Energy, 2012, 4, 514.

20 L. Yang, S. Jiang, Y. Zhao, L. Zhu, S. Chen, X. Wang, Q. Wu, J. Ma, Y. Ma and Z. Hu, Angew. Chem., Int. Ed., 2011, 50, 7132.

21 J. Ozaki, T. Anahara, N. Kimura and A. Oya, Carbon, 2006, 44, 3348.

22 E. Cruz-Silva, F. López-Urias, E. Munoz-Sandoval, B. Sumpter, et al., ACS Nano, 2009, 3(7), 1913.

23 E. Cruz-Silva, F. Lopez-Urias, E. Munoz-Sandoval, B. Sumpter, et al., Nanoscale, 2011, 3, 1008.

24 Z. W. Liu, F. Peng, H. J. Wang, H. Yu, W. X. Zheng and J. A. Yang, Angew. Chem., Int. Ed., 2011, 50, 3257.

25 Z. W. Liu, F. Peng, H. J. Wang, H. Yu, J. Tan and L. L. Zhu, Catal. Commun., 2011, 16, 35.

26 D. Deak, E. J. Biddinger, K. Luthman and U. S. Ozkan, Carbon, 2010, 48, 3635.

27 C. H. Choi, S. H. Park and S. Woo, ACS Nano, 2012, 6, 7084.

28 D. S. Yu, Y. H. Xue and L. M. Dai, J. Phys. Chem. Lett., 2012, 3, 2863.

29 R. Z. Yang, X. P. Qiu, H. R. Zhang, J. Q. Li, W. Zhu, Z. X. Wang, X. J. Huang and L. Q. Chen, Carbon, 2005, 43, 11.

30 R. Z. Yang, T. R. Dahn and J. R. Dahn, J. Electrochem. Soc., 2009, 156(4), B493.

31 D. A. Shirley, Phys. Rev. B: Solid State, 1972, 5, 4709.

32 D. Briggs and M. P. Seah, Practical Surface Analysis, Wiley Interscience, New York, 1990.

33 N. M. Markovic, H. A. Gasteiger and P. N. Ross, J. Phys. Chem., 1996, 100, 6715.

34 D. R. Lide, CRC Handbook of Chemistry and Physics, CRC Press, Boca Raton, FL, 1995.

35 J. Sunarso, A. A. Torriero, W. Zhou, P. C. Howlett and M. Forsyth, J. Phys. Chem. C, 2012, 116, 5827.
36 Y. Y. Liang, H. L. Wang, J. G. Zhou, Y. G. Li, J. Wang, T. Regier and H. J. Dai, J. Am. Chem. Soc., 2012, 134, 3517.

37 J. Du, Y. D. Pan, T. R. Zhang, X. P. Han, F. Y. Cheng and J. Chen, J. Mater. Chem., 2012, 22, 15812.

38 N. M. Markovic, T. J. Schmidt, V. Stamkovic and P. N. Ross, Fuel Cells, 2001, 105, 1.

39 K. Ghosh, M. Kumar, T. Maruyama and Y. Ando, Carbon, 2009, 47, 1565.

40 A. Oya and H. Marsh, J. Mater. Sci., 1982, 17, 309.

41 M. Yudasaka, K. Tasaka, R. Kikuchi, Y. Ohki and S. Yoshimura, J. Appl. Phys., 1997, 81, 7623.

42 H. Marsh, D. Crawford and D. W. Taylor, Carbon, 1983, 21, 81.

43 O. P. Krivoruchko and V. I. Zaikovskii, Kinet. Catal., 1998, 39, 561.

44 F. J. Derbyshire, A. E. Presland and D. L. Trimm, Carbon, 1975, 13, 111.

45 M. Sevilla and A. B. Fuertes, Carbon, 2006, 44, 468.

46 L. S. Dake, D. R. Baer and D. M. Friedrich, J. Vac. Sci. Technol., A, 1989, 7, 1634.

47 J. P. Paraknowitsch, Y. J. Zhang, B. Wienert and A. Thomas, Chem. Commun., 2013, 49, 1208.

48 M. Molinasabio, F. Rodriguezreinoso, F. Caturla and M. J. Selles, Carbon, 1995, 33, 1105.

49 A. M. Puziy, O. I. Poddubnaya, R. P. Socha, J. Gurgul and M. Wisniewski, Carbon, 2008, 46, 2113.

50 Q. F. Yi and L. H. Song, Electroanalysis, 2012, 24(7), 1655.

51 C. H. Choi, S. H. Park and S. I. Woo, J. Mater. Chem., 2012, 22, 12107.

52 L. Jiang, A. Hsu, D. Chu and R. Chena, J. Electrochem. Soc., 2009, 156(3), B370.

53 W. Yang, T.-P. Fellinger and M. Antonietti, J. Am. Chem. Soc., 2011, 133, 206.

54 H. Niwa, M. Kobayashi, K. Horiba, Y. Harada, M. Oshima, K. Terakura, T. Ikeda, Y. Koshigoe, J.-i. Ozaki, S. Miyata, S. Ueda, Y. Yamashita, H. Yoshikawa and K. Kobayashi, J. Power Sources, 2011, 196, 1006.

55 Z. R. Ismagilov, A. E. Shalagina, O. Y. Podyacheva, A. V. Ischenko, L. S. Kibis, A. I. Boronin, Y. A. Chesalov, D. I. Kochubey, A. I. Romanenko, O. B. Anikeeva, T. I. Buryakov and E. N. Tkachev, Carbon, 2009, 47, 1922.

56 D. Deng, L. Yu, X. Chen, G. Wang, L. Jin, X. Pan, J. Deng, G. Sun and X. Bao, Angew. Chem., Int. Ed., 2013, 52, 371. 